\title{
Severe Rhabdomyolysis Due to Adipsic Hypernatremia after Craniopharyngioma Surgery
}

\begin{abstract}
The association of diabetes insipidus and adipsia after craniopharyngioma surgery has high morbidity. Hypernatremia can be caused by adipsia and be aggravated by diabetes insipidus. Rhabdomyolysis rarely occurs. Case report: This is the first report of a diabetic patient with craniopharyngioma who developed diabetes insipidus and adipsia after surgery, evolving with severe hypernatremia that caused considerable rhabdomyolysis. Conclusion: The importance of the evaluation of muscle integrity when under hypernatremic states is pointed out. Although adipsia may have a simple solution through volunteer water ingestion, serious consequences such as repeated severe hypernatremia episodes and intense rhabdomyolysis with high morbidity could occur, if adipsia is not diagnosed. (Arq Bras Endocrinol Metab 2007;51/7:1175-1179)
\end{abstract}

Keywords: Rhabdomyolysis; Adipsia; Hypernatremia; Craniopharyngioma; Diabetes insipidus

\section{RESUMO}

\section{Rabdomiólise Grave Devido a Hipernatremia Adípsica após Cirurgia de Craniofaringioma.}

A associação de diabetes insipidus e adipsia após cirurgia de craniofaringioma implica em alta morbidade. Hipernatremia pode desenvolver-se devido a adipsia e ser agravada por diabetes insipidus. Rabdomiólise raramente ocorre. Descrição do caso: Esta é a primeira descrição de paciente diabético com craniofaringioma que desenvolveu diabetes insipidus e adipsia após a cirurgia, evoluindo com hipernatremia grave e conseqüente rabdomiólise maciça. Conclusão: Ressalta-se a necessidade de avaliar a integridade muscular na vigência de estados hipernatrêmicos. Apesar de apresentar solução simples, como ingestão voluntária de água, pode haver sérias conseqüências se o diagnóstico de adipsia não é realizado, como episódios repetidos de hipernatremia grave com rabdomiólise intensa e elevada morbidade. (Arq Bras Endocrinol Metab 2007;51/7:1175-1179)

Descritores: Rabdomiólise; Adipsia; Hipernatremia; Craniofaringioma; Diabetes insipidus

$\mathrm{D}$ IABETES INSIPIDUS CAN BE ASSOCIATED with craniopharyngioma, leading to increased morbidity. Adipsia or hypodipsia rarely occurs as a hypothalamic lesion. The association of these two osmolarity dysfunctions causes a significantly higher morbidity (1). Hypernatremia can emerge from adipsia and be aggravated by diabetes insipidus. Clinical manifestations include dehydration, muscular weakness, behavioural disturbances, apresentação de caso

DENISE E. ZANTUT-WITTMANN

Heraldo Mendes Garmes

ANITA DENARDO PANZAN

MARCELO DE OLIVEIRA LIMA

Maria Tereza Matias Baptista

Endocrinology Division, Faculty

of Medical Sciences, State

University of Campinas

(Unicamp), Campinas, SP.
Recebido em 08/02/07

Revisado em 18/05/07

Aceito em 06/08/07 
delirium, lethargy, and coma. Rhabdomyolysis is a rare occurrence in hyperosmolarity states, and can progress with acute renal insufficiency and myoglobinuria. Muscular weakness and pain are marked symptoms and the diagnosis is confirmed through the elevation of creatine phosphokinase (CK) (2).

We report herein a diabetic patient with craniopharyngioma who developed diabetes insipidus and adipsia, as a complication of surgical resection of a suprasellar tumour, leading to a hypothalamic lesion, presenting repeated dehydration episodes with severe hypernatremia and at least one episode of massive rhabdomyolysis

\section{CASE REPORT}

Male, 24 years, began his follow up in August 1997, presenting pubertal and growth delay, excessive weight gain and headache. Height $=1.63 \mathrm{~m}$; weight $=$ $74 \mathrm{~kg}$; pubertal stage G2P2 (Tanner); bone age = 14 years (chronological age $=17$ years, 10 months).

$\mathrm{He}$ presented amaurosis of the right eye and temporal hemianopsia of the left eye. Pituitary insufficiency was revealed in the functional evaluation, except for the normal prolactin and thyrotropin response and free thyroxin levels (table 1). Magnetic resonance imaging (MRI) of sella turcica showed a heterogeneous suprasellar expansive lesion, predominantly T1 hypointense and T2 hyperintense, with cystic areas and calcifications, displacing the $3^{\text {rd }}$ ventricle and columns of the posterior fornix, pressing the optic nerve and gyrating laterally the optic tracts, with no sella turcica invasion (figure 1). Cerebral arteriography was in accordance to a suprasellar expansive mass. Laboratory findings were normal, except for hyperglycemia ( 113 to $114 \mathrm{mg} / \mathrm{dL}$ ), leading to the diagnosis of diabetes mellitus. On November 1998, he was submitted to a surgical transfrontal tumour resection. The anatomopathological diagnosis was craniopharyngioma. He developed diabetes insipidus and hypernatremia $(\mathrm{Na}=173 \mathrm{mEq} / \mathrm{L}$; reference values $-\mathrm{RV}$ : 133-145). He was normokalemic ( $\mathrm{K}=3.4 \mathrm{mEq} / \mathrm{L}$, $\mathrm{RV}=3.3-5.1)$. He started on intranasal Desmopressin-DDAVP $(30 \mu \mathrm{g} /$ day $)$. Pituitary function was totally insufficient.

MRI (March/2002) showed gyrus rectus atrophy, slight hypothalamic irregularity, free optic nerves, no identification of pituitary stalk, and no signs of recurrence. Bone age $=15$ years $($ chronological age $=$ 19 years, 01 month); Visual fields: lower lateral quadrantopsia of the right eye and lateral hemianopsia of the left eye.

He was admitted 6 times at the Emergence Unit (January/1999 through August/2003), presenting weakness and muscular pain, dehydration, hypernatremia (158 to $173 \mathrm{mEq} / \mathrm{L})$, hyperglycemia (126; $101 ; 116 ; 120 ; 224 \mathrm{mg} / \mathrm{dL})$ and once with hyperglycemic ketosis $(980 \mathrm{mg} / \mathrm{dL}, \mathrm{Na}=161 \mathrm{mEq} / \mathrm{L}, \mathrm{K}=$ $4.3 \mathrm{mEq} / \mathrm{L})$. He was always normokalemic. In September $/ 2003$, he referred to intense and generalized muscular pain weakness for the past two days and denied any thirst sensation. Laboratory findings: $\mathrm{CK}=$ $13,775 \mathrm{IU} / \mathrm{L}(\mathrm{RV}<170), \mathrm{Na}=165 \mathrm{mEq} / \mathrm{L}, \mathrm{K}=3.6$ $\mathrm{mEq} / \mathrm{L}$, glucose $=224 \mathrm{mg} / \mathrm{dL}$, Calcium $(\mathrm{Ca})=8.9$ $\mathrm{mg} / \mathrm{dL}(\mathrm{RV}=8.6-10.0)$, inorganic phosphorus $(\mathrm{Pi})=$ $4.1 \mathrm{mg} / \mathrm{dL}(\mathrm{RV}=2.7-4.5)$, urea $=74 \mathrm{mg} / \mathrm{dL}(\mathrm{RV}<$ $49)$, creatinine $=1.48 \mathrm{mg} / \mathrm{dL}(\mathrm{RV}<1.2)$. A CK peak was observed 24 hours after admission $(\mathrm{CK}=21,261$ $\mathrm{IU} / \mathrm{L}, \mathrm{Na}=171 \mathrm{mEq} / \mathrm{L}, \mathrm{K}=4.2 \mathrm{mEq} / \mathrm{L})$, and an acute non-oliguric renal insufficiency ensued as a complication. Daily CK (figure 2), natremia, and renal function were determined. The diagnosis was acute myopathy secondary to adipsic hypernatremia as a consequence of cranipharyngioma surgery. The treatment was based on natremia correction with intra-

Table 1. Pituitary functional evaluation before craniopharyngioma surgery.

\begin{tabular}{|c|c|c|c|c|c|c|c|}
\hline Time & Glucose & hGH & Cortisol & Prolactin & TSH & LH & FSH \\
\hline $0^{\prime}$ & 82 & 1.42 & 10.0 & 10.5 & 1.32 & 0.4 & 0.4 \\
\hline $15^{\prime}$ & 40 & $<0.5$ & & 27.4 & 10.48 & 0.8 & 1.3 \\
\hline $30^{\prime}$ & 33 & 2.8 & 9.8 & 27.3 & 14.55 & 0.6 & 1.7 \\
\hline $45^{\prime}$ & 66 & $<0.5$ & & & & 0.9 & 1.7 \\
\hline $60^{\prime}$ & 73 & 0.52 & 14.0 & & & 0.7 & 2.2 \\
\hline $90^{\prime}$ & 79 & 2.5 & & & & & \\
\hline BRV & $<100 \mathrm{mg} \%$ & $<2.5 \mathrm{ng} / \mathrm{mL}$ & $5.4-25 \mu \mathrm{g} / \mathrm{dL}$ & $<15 \mathrm{ng} / \mathrm{mL}$ & $\begin{array}{c}0.41-4.15 \\
\mu \mathrm{IU} / \mathrm{mL}\end{array}$ & $\begin{array}{r}1.7-8.6 \\
\mathrm{mIU} / \mathrm{mL}\end{array}$ & $\begin{array}{l}1.5-12.4 \\
\mathrm{mIU} / \mathrm{mL}\end{array}$ \\
\hline
\end{tabular}

$\mathrm{FT}_{4}=0.86 \mathrm{ng} \%(\mathrm{BRV}=0.74-2.1)$

BRV = Basal Reference Values; $\mathrm{FT}_{4}=$ Free Thyroxin; $\mathrm{hGH}=$ human Growth Hormone; $\mathrm{TSH}=$ Thyrotropin;

$\mathrm{LH}=$ Luteinizing Hormone; FSH = Follicle Stimulating Hormone. 


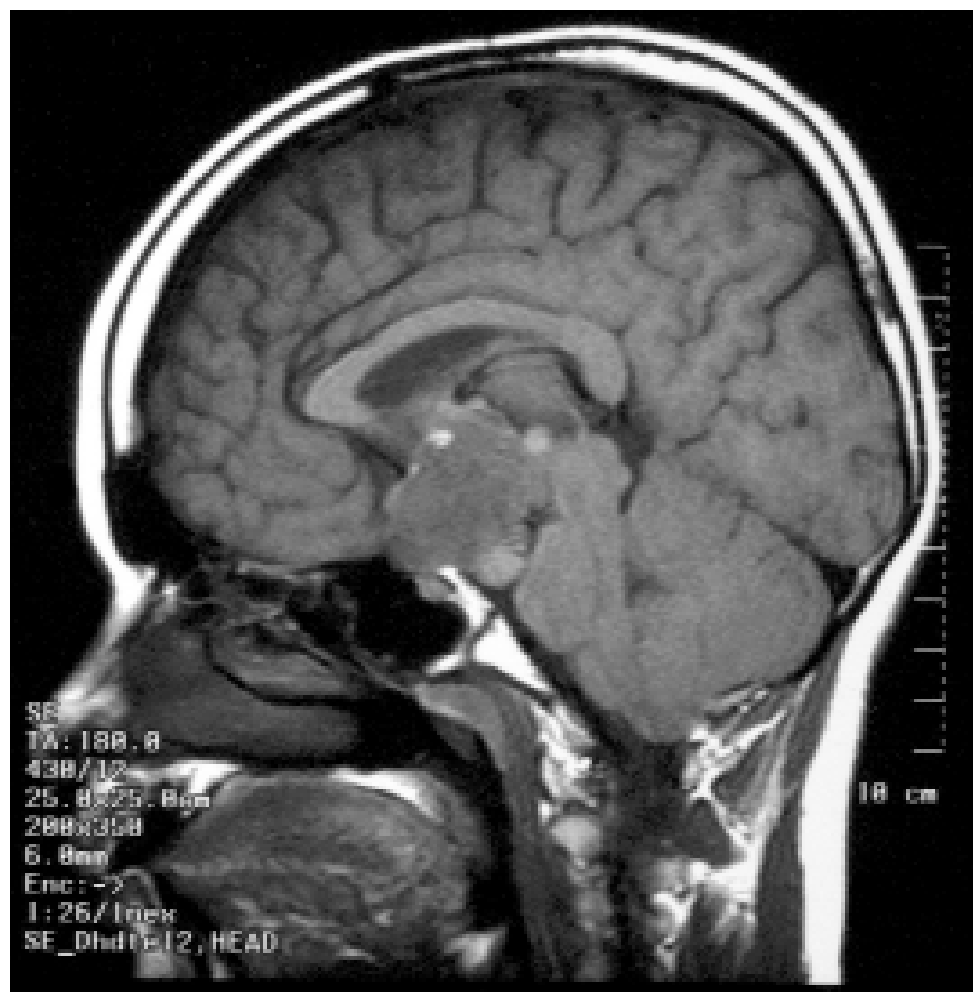

Figure 1. Magnetic resonance imaging of sella turcica showing a suprasellar expansive lesion in contact with the encephalic trunk, accomplishing the $3^{\text {rd }}$ ventricle.

$\mathrm{mEq} / \mathrm{L}$



Figure 2. Graph representing serum creatine phosphokinase (CK) and sodium $(\mathrm{Na})$ during the $6^{\text {th }}$ hospital admission of the patient. 
venous hydration and on oriented and assisted water intake. After the reduction of CK levels and normalisation of renal function, the patient was instructed to maintain continuous DDAVP use and regular and periodic water ingestion. Glucose control was attained with NPH and regular insulin and metformin.

Post-surgical visual field alterations remained unchanged. The muscle integrity follow up was performed through periodic $\mathrm{CK}, \mathrm{Na}$, and $\mathrm{K}$ serum determinations. His treatment includes daily prednisone, Lthyroxine, NPH and regular insulin, and monthly testosterone propionate.

$\mathrm{He}$ is now asymptomatic, although he has presented some mild to moderate episodes of dehydration and consequences, resolved with outpatient treatment as in June/2004: $\mathrm{CK}=569 \mathrm{IU} / \mathrm{L}, \mathrm{Na}=147 \mathrm{mEq} / \mathrm{L}, \mathrm{K}$ $=3.2 \mathrm{mEq} / \mathrm{L}$, creatinine clearance $=113 \mathrm{~mL} / \mathrm{min} / 1.72$ $\mathrm{m}^{2} ;$ glucose $=102 \mathrm{mg} / \mathrm{dL}, \mathrm{HbAlc}=5.8 \%(\mathrm{RV}=$ 3.9-6.1) and in February/2006: CK = 1,258 IU/L, Na $=146 \mathrm{mEq} / \mathrm{L}, \mathrm{K}=3.4 \mathrm{mEq} / \mathrm{L}$, creatinine $=0.94$ $\mathrm{mg} / \mathrm{dL}$; glucose $=84 \mathrm{mg} / \mathrm{dL}, \mathrm{HbAlc}=6.5 \%$.

\section{DISCUSSION}

Hypernatremia secondary to dehydration or to excessive saline administration is rare in healthy young adults. In hospitalised patients, hypernatremia is usually secondary to erroneous intravenous administration of sodium (3). Only rarely do patients with craniopharyngioma develop adipsia or hypodipsia secondary to a tumour located in the hypothalamic region. However, it is more common following surgery, occurring in approximately $20 \%$ of the cases (4). These alterations can lead to hypernatremic states that can unchain severe dehydration episodes, as well as behavioural disturbances, delirium, lethargy, coma, and muscular weakness due to rhabdomyolysis $(1,2)$. Rhabdomyolysis is a rare osmolarity disturbance complication, characterised by muscular weakness and pain. Significant CK levels confirm the diagnosis. Acute renal failure and myoglobinuria may accompany the clinical picture. Immediate consequences of muscle destruction include hyperkalemia (increasing the risk of fatal heart arrhythmia) and hypocalcemia. Acute renal insufficiency is the result of renal vasoconstriction, intratubular myoglobin deposition, and nephrotoxicity caused by heme containing proteins (5). Hypokalemia, hypophosphatemia, and hyponatremia are uncommon causes of rhabdomyolysis (5). Rhabdomyolysis can also be associated to the hyperosmolarity of diabetic coma $(6,7)$. Hypernatremia causing myopathy has been reported only a few times and the association with renal impairment is much more rare $(2,8)$. One of the explanations for the development of muscle lesion by hypernatremia could be the inhibition of $\mathrm{Na}-\mathrm{K}$ transporter in the cytoplasm membrane (1). In patients whose myopathy was associated to hypernatremia (160 to $180 \mathrm{nmol} / \mathrm{L}$ ), CK levels ranged from 500 to $60,000 \mathrm{UI} / \mathrm{L}$ and the occurrence of acute renal insufficiency was not rare. In some cases there was an association with germinoma, pinealoma, optic glioma or cerebral ischaemia. Diabetes insipidus was present in only a few cases $(2,6,8,9)$. In this case, in addition to dehydration, the patient complained of intense pain and muscular weakness. Although he presented severe dehydration and hyperglicemia, he did not mention thirst, information essential in order to establish the diagnosis of adipsia. Hypernatremia aggravated by dehydration and hyperglycemia can explain the aetiology of myopathy and acute renal insufficiency. The latter is probably due to myoglobin toxicity resulting from the rhabdomyolisis process after dehydration. It is relevant to highlight that the patient was euthyroid, normokalemic, normocalcemic, and normophosphatemic during rhabdomyolisis, hence the episodes were not precipitated by such metabolic disturbances. Muscle lesion was confirmed by extremely elevated CK levels, with a peak of 21,261 IU/L about $24 \mathrm{~h}$ after the admission. In such acute episodes, the treatment for dehydration corrected other hydro-electrolytic disturbances. Life long treatment of adipsia is needed to maintain a normal hydroelectrolytic balance, through systematic stimulated and regular water ingestion (1). Additionally, a periodic evaluation of sodium and CK serum levels is obligatory in these patients due to the frequent oligosymptomatic occurrence of mild or moderate dehydration and consequent rhabdomyolysis. This is the first report of a diabetic patient with craniophryngioma who developed diabetes insipidus and adipsia as a complication of a hypothalamic tumour surgery, associated with hyperglycemia, contributing to the hyperosmolarity, evolving with hypernatremia and hydro-electrolytic imbalance that provoked severe rhabdomyolysis and acute renal insufficiency.

We would like to emphasise the need to establish the diagnosis of adipsia and the evaluation of muscle integrity in hypernatremic states. Although the solution for adipsia is simple, through volunteer water intake, if not diagnosed, serious consequences can occur such as repeated hypernatremia episodes, due to dehydration, and intense rhabdomyolysis with elevated morbidity. 


\section{REFERENCES}

1. Macias Batista A, Martinez Martins FJ, de Plabos Velasco PL. Diabetes insipidus and adpsic hypernatremia in a patient with craniopharyngioma. An Med Interna 1999;16:87-8.

2. Hiromatsu K, Kobayashi T, Fujii N, Itoyama Y, Goto I, Murakami J. Hypernatremic myopathy. J Neurol Sci 1994;122:144-7.

3. Ofran Y, Lavi D, Opher D, Weiss TA, Elinav E. Fatal voluntary salt intake resulting in the highest ever documented sodium plasma level in adults (255 $\left.\mathrm{mmol} \mathrm{L}^{-1}\right)$ : a disorder linked to female gender and psychiatric disorders. J Int Med 2004;256:525-8.

4. Smith D, Finucane F, Phillips $\mathrm{J}$, Baylis $\mathrm{PH}$, Ficacane $\mathrm{J}$, Tormey $W$, et al. Abnormal regulation of thirst and vasopressin secretion following surgery for craniopharyngioma. Clin Endocrinol (Oxf) 2004:61(2):273-9.

5. Lane R, Phillips M. Rhabdomyolisis. BMJ 2003;327:115-6.

6. Kung AWC, Pun KK, Lam KSL, Yeung RTT. Rhabdomyolisis associated with cranial diabetes insipidus. Postgrad Med J 1991;67:912-3.

7. Singhal PC, Abramovici M, Ayer S, Desroches L. Determinants of rhabdomyolysis in the diabetic state. Am J Nephrol 1991;11:447-50.
8. Asahara H, Maruyama S, Motomura S, Tamura K, Mioshi T. A case of severe hypernatremia complicated with rhabdomyolysis. Rinsho Shinkeigaku 1998;38:301-4.

9. Acquarone N, Garibotto G, Pontremoli R, Gurreri G. Hypernatremia associated with severe rhabdomyolysis. Nephron 1989;51:441-2.

Endereço para correspondência:

Denise Engelbrecht Zantut-Wittmann

Disciplina de Endocrinologia

Departamento de Clínica Médica

Faculdade de Ciências Médicas

Universidade Estadual de Campinas (Unicamp)

Caixa Postal 6111

Rua Tessália Vieira de Camargo 126

13084-971 Campinas, SP

Fax: (19) 3521-7408

E-mail: zantutw@fcm.unicamp.br 